\title{
DYNAMIC ANALYSIS OF COMPOSITE STEEL COLUMNS INFILLED WITH LIGHT WEIGHT CONCRETE (LWC) USING MATLAB
}

\author{
Ramya Shree S C ${ }^{1}$, N. S. Kumar ${ }^{2}$ \\ ${ }^{1}$ Student, Dept. Civil Engineering, Ghousia College of Engineering Ramanagaram, Karnataka, India \\ ${ }^{2}$ Professor \& Director $(R \& D)$, Dept. Civil Engineering, Ghousia College of Engineering Ramanagaram, Karnataka, \\ India
}

\begin{abstract}
The Composite Steel Column consists of both Steel and Concrete as main components. In this study, the load carrying capacity of CFST will be determined for Light Weight Concrete by developing programs using MATLAB software. The behavior of CFST plays an important role in Seismic design. In this study, the Light Weight Concrete is used as infilled materials of different grades of concrete like M20, M30, and M40. The required data of CFST columns like length, diameter, and weight are taken from different National \& International research works, including R\&D works carried out at Civil Engineering Research Laboratory at Ghousia College of Engineering, Ramanagaram by previous UG, PG \& Research Scholars since 2010 till date. In this study, both Long and Short columns are considered. Percentage errors between Experimental, Analytical values and MATLAB results are studied in detail according to Slenderness Ratio of CFST columns. Results are compared with available codes like EUROCODE 4, ACI, BS5400 and suitable conclusions are drawn.
\end{abstract}

Keywords: Light Weight Concrete, Filled steel tubes, Hollow CFST, MATLAB R2013a etc...

\section{INTRODUCTION}

The Composite Steel Columns are composed of both Steel and Concrete components. The solid filled steel tubes has been utilized as a part of numerous zones which is principally similar to segment supporting structures like multi-storey buildings, roof of oil stockpiling tanks, columns for vast modern workshops. Because of its basically proficient load bearing limit the solid filled steel tubes utilizes as segments in multi storied structures which is expanded in late decades.

The concrete filled steel tubes were developed during $19^{\text {th }}$ century. And the composite steel columns have a many excellent structural properties such as high compressive strength, large ductility and large energy absorption capacity. Concrete steel tubes are used for both unbraced and propped gathering structures.

The typical figures of CFST sections are as shown in below figure.

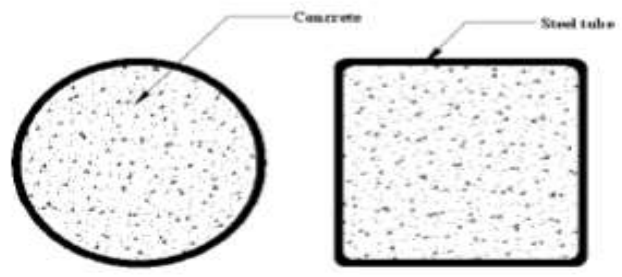

Fig 1: Typical Cross Section of CFST

\subsection{Description of Software Used}

The name of the software MATLAB stands for matrix laboratory. The MATLAB is a high performance language for technical computing. The 3D modeling of CFST columns infilled with LWC and also hollow CFST columns are modeled by developing MATLAB programs.

Light Weight Concrete filled in CFST columns and hollow columns are accurately modeled in MATLAB R2013a software. The results are verified with available codes.

\section{FINITE ELEMENT MODELING}

The finite element modeling of CFST columns are done using MATLAB (R2013a) software by developing the programs,

\subsection{Material Properties}

The properties of Steel and Concrete are considered as follows

Steel properties:

Young's modulus of steel $\left(E_{\mathrm{s}}\right)=200 \mathrm{GPA}$

Poisons ratio $=0.3$

Density of steel $=7860 \mathrm{Kg} / \mathrm{m}^{3}$

Concrete Properties:

Young's modulus of concrete $\left(\mathrm{E}_{\mathrm{c}}\right)=0.0095\left(\mathrm{f}_{\mathrm{cyl}}+8\right)^{0.3}$ (by referring the journals by the Author of ARTIOMAS KURANOVAS')

Poisons ratio $=0.2$

Density of concrete $=2200 \mathrm{Kg} / \mathrm{m}^{3}$ 


\subsection{Modeling of CFST Columns}

The 3D modeling of CFST columns of LWC as an infilled material and hollow CSFT columns for above properties are created by developing the MATLAB programs. The MATLAB programs is as shown in below $\% \%$ PRAMETER DECLARATION SECTION

LENGTH $=202.2 ; \%$ Length in $\mathrm{mm}$

Outer_Dia $=33.7 ; \%$ Outer Diameter in $\mathrm{mm}$ Inner_Dia $=27.3 ; \%$ Inner Diameter in $\mathrm{mm}$ Weight_in_gram $=540 ; \%$ Weight in Grams Grades $=20 ; \%$

Load $=182450 ; \%$

E_s=20000;\% $\mathrm{g}=9.81 \%$

Mass=Weight_in_gram/g; \%

$\% \%$ Moment of Inertia, I = Is + Ic (mm4)

I_s $=3.14 *(($ Outer_Dia^4) $)($ Inner_Dia^4) $) / 64$;

I_c $=3.14 *\left(\right.$ Inner_Dia $\left.{ }^{\wedge} 4\right) / 64$;

I=I_s+I_c;

$\% \%(\mathrm{EI}) \mathrm{eff}=\mathrm{Es}$ Is $+\mathrm{C} 3 \mathrm{Ec}$ Ic $(\mathrm{Nmm} 2)$

A_s $=3.14 *(($ Outer_Dia^2)-(Inner_Dia^2) $) / 4$;

A_c $=3.14 *($ Inner_Dia^2)/4;

C3_C3_0_9=0.6+2*(A_s/(A_c+A_s) );

E_c $=(5000 *(\operatorname{sqrt}($ Grades $))) *\left(2.3544 * 10^{\wedge}-5\right)$;

E_I_eff=(E_s*I_s $)+(0.8 * E$ E*I_c $)$;

$\% \%$ TO FIND STIFFNESS AND NATURAL

FREQUENCY

eff_Length $=0.65 *$ LENGTH;

Stiffness $=(12 *$ E_I_eff $) /$ eff_Length^ 3 ;

$\operatorname{disp}($ 'Stiffness');

disp(Stiffness);

Natural_Frequency=sqrt(Stiffness/Mass);

disp('Natural_Frequency');

disp(Natural_Frequency);
$\% \%$ TO FIND FOR COLUMN VIBRATION AND FOR COLUMN BUCKLING

COLUMN_VIBRATION_Lambda1 $=\left(\left(\operatorname{Load}+\left(\left(\operatorname{Load}^{\wedge} 2\right)+(4\right.\right.\right.$ $* 78000000 *((3.14 *$ Outer_Dia^2)/4 $) * E$ I_eff*Natural_Freq uency $\left.\left.\left.{ }^{\wedge} 2\right)\right)^{\wedge} 0.5\right) /(2 *$ E_I_eff $\left.)\right)^{\wedge} 0.5$;

disp('COLUMN_VIBRATION_Lambda1'); disp(COLUMN_VIBRATION_Lambda1);

COLUMN_VIBRATION_Lambda $2=((-$

Load $+\left(\left(\operatorname{Load}^{\wedge} 2\right)+\left(4 * 78000000 *\left(\left(3.14 *\right.\right.\right.\right.$ Outer_Dia^$\left.\left.{ }^{\wedge}\right) / 4\right) * \mathrm{E}_{-}$

I_eff*Natural_Frequency^2) $\left.)^{\wedge} 0.5\right) /(2 * E$ I_eff $\left.)\right)^{\wedge} 0.5$;

disp('COLUMN_VIBRATION_Lambda2');

disp(COLUMN_VIBRATION_Lambda2);

COLUMN_BUCKLING_Lambda1=(Load/E_I_eff $)^{\wedge} 0.5$;

disp('COLUMN_BUCKLING_Lambda1');

disp(COLUMN_BUCKLING_Lambda1);

$\% \%$ TO FIND THE CRITICAL LOADING FOR INFILLED

critical_loading $=\left(\left(\mathrm{pi}^{\wedge} 2\right)^{*} \mathrm{E} \_\mathrm{I} \_\right.$eff $) / \mathrm{LENGTH}^{\wedge} 2$;

disp('CRITICAL LOADING');

disp(critical_loading);

$\% \% 3-D$ CFST COLUMN INFILLED LWC

$\mathrm{t}=$ linspace $(0,2 *$ pi);

$\operatorname{rin}=0.27$

rout $=0.3$

center $=[0,0]$;

$\operatorname{zin}=\operatorname{rin} * \cos (\mathrm{t})$;

zout $=$ rout $* \cos (\mathrm{t})$

yin $=\operatorname{rin} * \sin (t)$

yout $=$ rout $* \sin (\mathrm{t})$

$\mathrm{x} 1=0$;

$\mathrm{x} 2=1$;

figure(1);

After developing the above programme, the 3D modelling of CFST columns will be as shown in below figure.

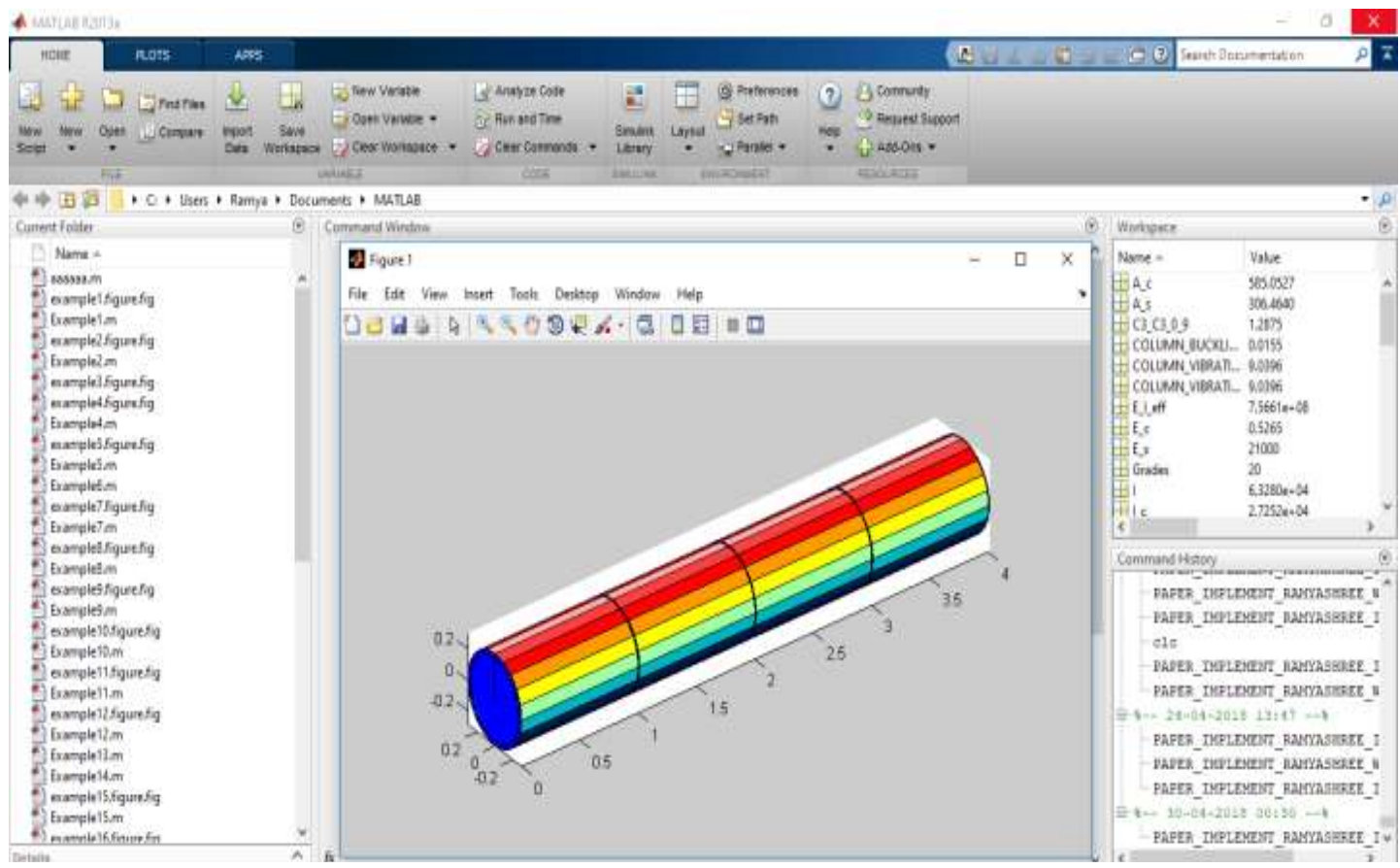

Fig 2: 3D Modelling of CFST column 
The Natural Frequencies, Modal Frequencies and also

Critical load of CFSTs are generated by using MATLAB programme. The output results are as shown in figure $3,4$.

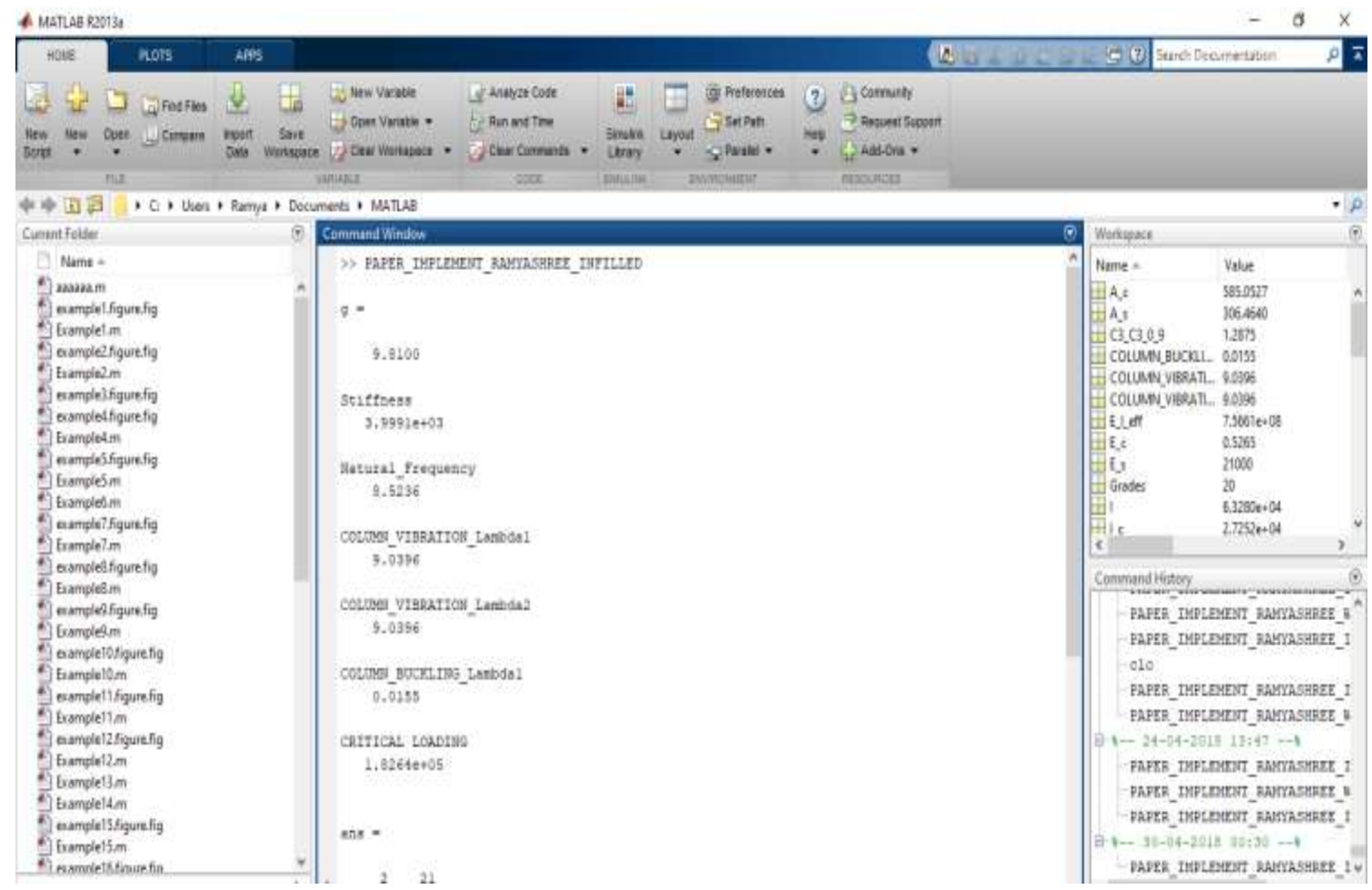

Fig 3: Output results of MATLAB

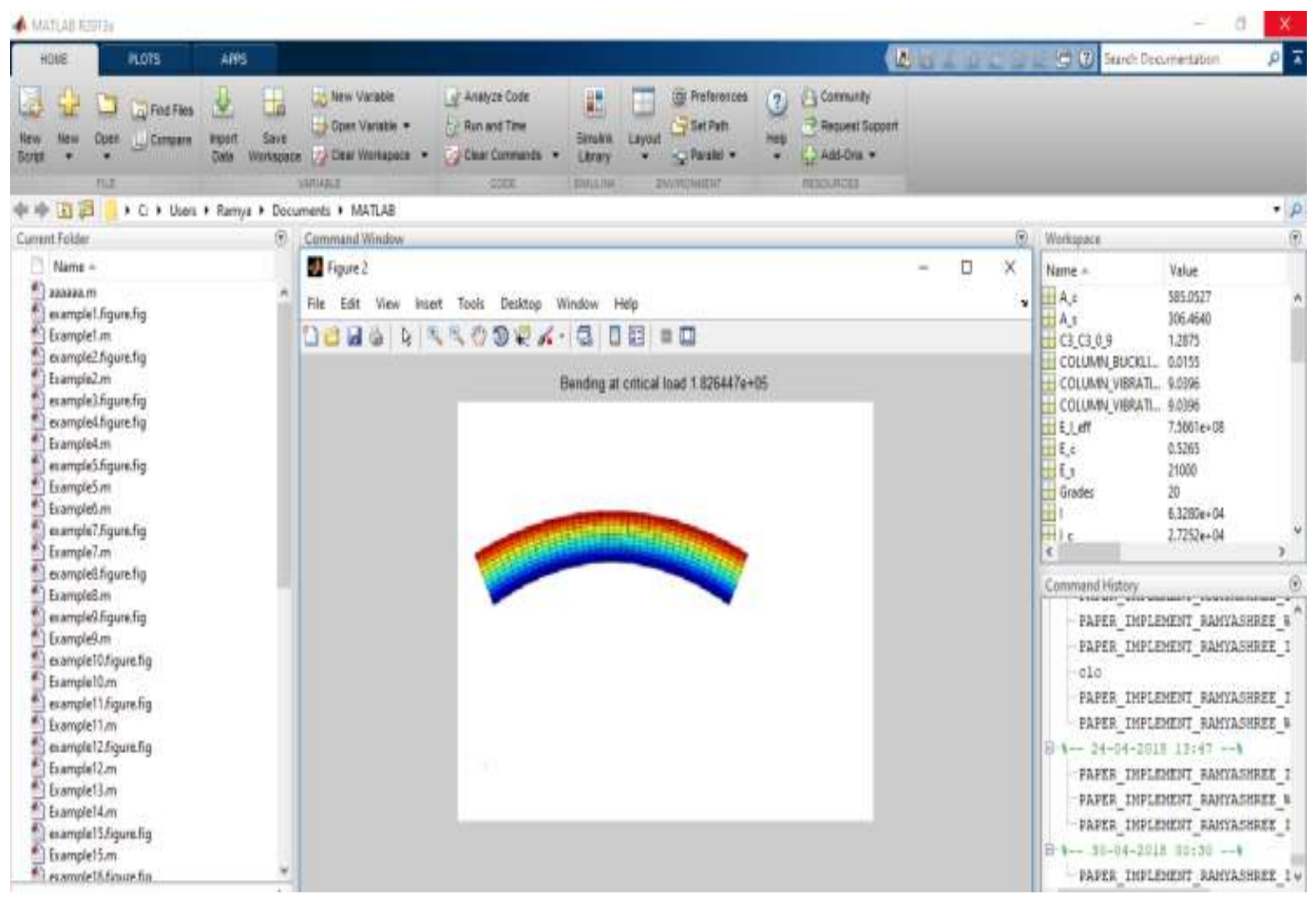

Fig 4: Buckling of CFST column 


\section{SOLUTION PROCEDURES}

The results of Natural Frequencies and Modal Frequencies of CFST columns and also Critical load of CFST columns (for both infilled LWC and hollow CFST) for different L/D ratios and also for different grades of concrete like M20, M30, M40 are calculated by using below procedures.

\subsection{Natural frequency}

The natural frequency of CFST columns are calculated by using below formula

$$
\mathrm{w}_{(\mathrm{rdd})}=(\mathrm{k} / \mathrm{m})^{0.5}
$$

Where, $\mathrm{w}=$ Natural frequency in $\mathrm{rad}$

$\mathrm{k}=$ stiffness of CFST in $\mathrm{N} / \mathrm{mm}$

$\mathrm{m}=$ mass of CFST in $\mathrm{N}-\mathrm{sec}^{2} / \mathrm{mm}$

\subsection{Modal Frequencies}

The Modal Frequency for CFST is calculated by using the following formula

For column vibration:

$\left.\lambda_{1=} \operatorname{sqrt}\left(\mathrm{P}+\mathrm{P}^{2}+4 \rho^{*} \operatorname{sqrt}\left(\left(\pi^{*} \mathrm{D}^{2} / 4\right) * \mathrm{EI}^{*} \mathrm{~W}_{\mathrm{n}}{ }^{2}\right)\right) /(2 * \mathrm{EI})\right)$

$\left.\lambda_{2}=\operatorname{sqrt}\left(-\mathrm{P}+\mathrm{P}^{2}+4 \rho^{*} \operatorname{sqrt}\left(\left(\pi^{*} \mathrm{D}^{2} / 4\right) * \mathrm{EI}^{*} \mathrm{w}_{\mathrm{n}}{ }^{2}\right)\right) /(2 * \mathrm{EI})\right)$

Where, $\mathrm{P}=$ crippling load in $\mathrm{N}$

$\mathrm{D}=$ Outer diameter in $\mathrm{mm}$

$\mathrm{W}_{\mathrm{n}}=$ Natural frequency in $\mathrm{rad}$

For column buckling:

$$
\lambda_{1}=\operatorname{sqrt}(\mathrm{P} / \mathrm{EI})
$$

\subsection{Critical Load}

To check the accuracy of Critical loading obtained from MATLAB are compared with available codes. The Critical loading of CFST columns are calculated by using the formula as mentioned in below.

$$
\mathrm{N}_{\mathrm{cr}}=\left(\pi^{2}(\mathrm{EI})_{\mathrm{eff}}\right) / \mathrm{L}^{2}
$$

Where (EI) eff=effective elastic flexural stiffness of concrete sections, and $\mathrm{L}$ is the buckling length of column.

$$
\begin{aligned}
& (E I)_{e f f}=E_{a} I_{a}+0.8 E_{c d} I_{c} \text { for short columns } \\
& (E I)_{e f f}=E_{a} I_{a}+0.6 E_{c} I_{c} \text { for short columns }
\end{aligned}
$$

Where $I_{a}$ and $I_{c}$ are the moment of inertia of steel and concrete.

$\mathrm{E}_{\mathrm{a}}=$ elastic modulus of steel structures.

$\mathrm{E}_{\mathrm{cd}}=\mathrm{E}_{\mathrm{cm}} / \gamma_{\mathrm{c}}$

$\mathrm{E}_{\mathrm{cm}}=$ mean value of concrete elasticity modulus

$\gamma_{c}=$ partial safety factor of concrete which is reduced to 1.35
The results are compared with following codes:

\subsubsection{Euro Code 4}

The Critical load of CFST columns are calculated by using below formula according to Euro code 4

$$
\mathrm{N}_{\mathrm{cr}}=\mathrm{A}_{\mathrm{s}} \mathrm{f}_{\mathrm{s}}+\mathrm{A}_{\mathrm{c}} \mathrm{f}_{\mathrm{c}}
$$

\subsubsection{ACI Code}

The Critical load of CFST columns are calculated by using the below formula according to American Concrete Institute $\mathrm{N}_{\mathrm{cr}}=\mathrm{A}_{\mathrm{s}} \mathrm{f}_{\mathrm{s}}+0.85 \mathrm{~A}_{\mathrm{c}} \mathrm{f}_{\mathrm{c}}$

\subsubsection{BS5400 Code}

The Critical load of CFST columns are calculated by using the below formula according to British Standards 5400

$\mathrm{N}_{\mathrm{cr}}=\mathrm{A}_{\mathrm{s}} \mathrm{f}_{\mathrm{s}}+0.675 \mathrm{~A}_{\mathrm{c}} \mathrm{f}_{\mathrm{c}}$

Where, $A_{s}=$ area of steel in $\mathrm{mm}^{2}$

$\mathrm{f}_{\mathrm{s}}=$ yield strength of steel in $\mathrm{N} / \mathrm{mm}^{2}$

$\mathrm{A}_{\mathrm{c}}=$ area of concrete in $\mathrm{mm}^{2}$

$\mathrm{f}_{\mathrm{c}}=$ characteristic strength of concrete in $\mathrm{N} / \mathrm{mm} 2$

\section{VERIFICATIONS OF RESULTS}

The Experimental, Analytical, MATLAB results of Natural

\begin{tabular}{|c|c|c|c|}
\hline $\begin{array}{c}\text { Lengt } \\
\mathrm{h}\end{array}$ & $\begin{array}{c}\text { Grade } \\
\mathrm{s}\end{array}$ & $\begin{array}{c}\text { Natural } \\
\text { frequency(Analyt } \\
\text { ic) }\end{array}$ & $\begin{array}{c}\text { Natural } \\
\text { frequency(MATLA } \\
\text { B) }\end{array}$ \\
\hline $\begin{array}{c}\mathrm{L} \\
(\mathrm{mm})\end{array}$ & M & $\mathrm{w}(\mathrm{rad})$ & $\mathrm{w}(\mathrm{rad})$ \\
\hline \multirow{4}{*}{202.2} & M20 & 8.318144571 & 8.5236 \\
\hline & M30 & 7.738045 & 7.9291 \\
\hline & M40 & 7.54695 & 7.7333 \\
\hline & $\begin{array}{c}\text { Hollo } \\
\text { W }\end{array}$ & 8.99288 & 9.234 \\
\hline \multirow{4}{*}{254.4} & M20 & 6.0263477 & 6.186 \\
\hline & M30 & 5.939948 & 6.053 \\
\hline & M40 & 5.877537 & 6.034 \\
\hline & $\begin{array}{c}\text { Hollo } \\
\text { W }\end{array}$ & 7.952923 & 8.152 \\
\hline \multirow{4}{*}{339.2} & M20 & 3.963534 & 4.1254 \\
\hline & M30 & 3.91782 & 4.0012 \\
\hline & M40 & 3.71541 & 3.8081 \\
\hline & $\begin{array}{c}\text { Hollo } \\
\text { W }\end{array}$ & 4.8406466 & 4.9821 \\
\hline \multirow{4}{*}{424} & M20 & 2.089496 & 2.1542 \\
\hline & M30 & 1.96344787 & 2.01325 \\
\hline & M40 & 1.9357695 & 2.0124 \\
\hline & Hollo & 2.649766192 & 2.7235 \\
\hline
\end{tabular}
frequencies and Modal Frequencies and also Critical loading of CFST columns (for both infilled LWC and hollow) of different $\mathrm{L} / \mathrm{D}$ ratio and also different grades of concrete are compared with codes is as shown in below

Table 1: Comparison of Natural Frequency with MATLAB 


\begin{tabular}{|c|c|c|c|}
\hline & W & & \\
\hline \multirow{4}{*}{508.8} & M20 & 1.516685 & 1.5683 \\
\hline & M30 & 1.46175 & 1.4978 \\
\hline & M40 & 1.41381 & 1.4512 \\
\hline & $\begin{array}{c}\text { Hollo } \\
\text { w }\end{array}$ & 1.81067166 & 1.8592 \\
\hline \multirow{4}{*}{594.6} & M20 & 1.058918 & 1.1534 \\
\hline & M30 & 1.042125001 & 1.0684 \\
\hline & M40 & 1.0278495 & 1.0546 \\
\hline & $\begin{array}{c}\text { Hollo } \\
\text { w }\end{array}$ & 1.33913 & 1.3856 \\
\hline \multirow{4}{*}{678.4} & M20 & 1.014745 & 1.3845 \\
\hline & M30 & 1.0114761 & 1.0364 \\
\hline & M40 & 1.011247 & 1.01145 \\
\hline & $\begin{array}{c}\text { Hollo } \\
\text { w }\end{array}$ & 1.150548 & 1.1834 \\
\hline
\end{tabular}

Natural Frequency vs length of CFST

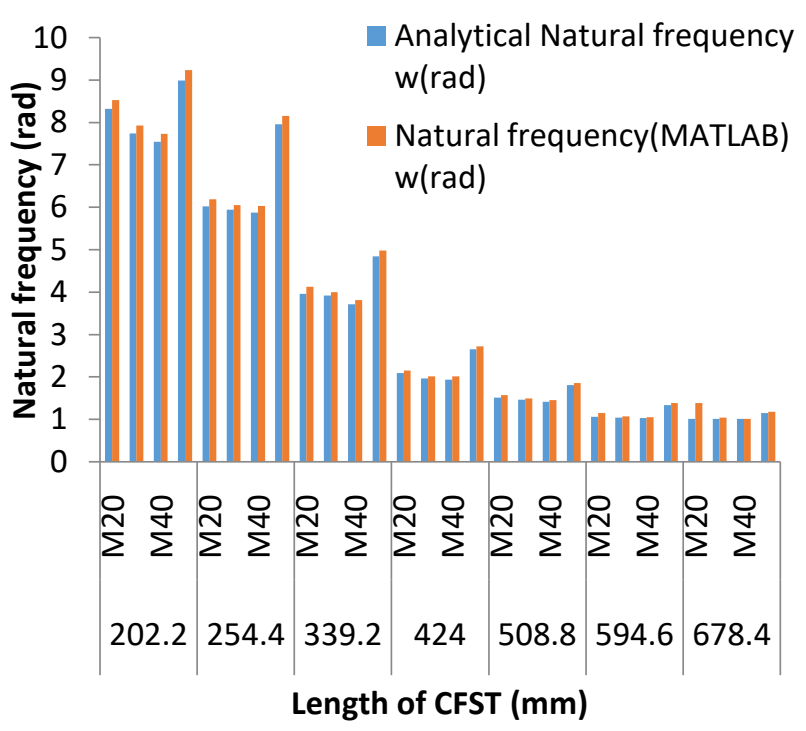

Chart 1: Natural Frequency v/s length of CFST

Table 2: comparison of modal frequencies for $202.2 \mathrm{~mm}$ length

\begin{tabular}{|c|c|c|c|c|c|c|c|}
\hline \multirow{2}{*}{$\mathrm{L}$} & \multirow{2}{*}{ Grades } & \multicolumn{3}{|c|}{ Modal } & \multicolumn{3}{c|}{ Modal } \\
& & \multicolumn{2}{|c|}{ Frequency(Analy) } & \multicolumn{2}{c|}{ Frequency(MATLAB) } \\
\cline { 2 - 8 } & $\mathrm{M}$ & $\lambda 1$ & $\lambda 2$ & $\lambda 3$ & $\lambda 1$ & $\lambda 2$ & $\lambda 3$ \\
\hline \multirow{4}{*}{202.2} & 20 & 9.03 & 9.03 & 0.01 & 9.03 & 9.03 & 0.01 \\
\cline { 2 - 8 } & 30 & 8.71 & 8.71 & 0.01 & 8.71 & 8.71 & 0.01 \\
\cline { 2 - 8 } & 40 & 8.61 & 8.61 & 0.01 & 8.61 & 8.61 & 0.01 \\
\cline { 2 - 8 } & Hollow & 9.39 & 9.39 & 0.01 & 9.41 & 9.41 & 0.01 \\
\hline
\end{tabular}

Length v/s modal frequencies

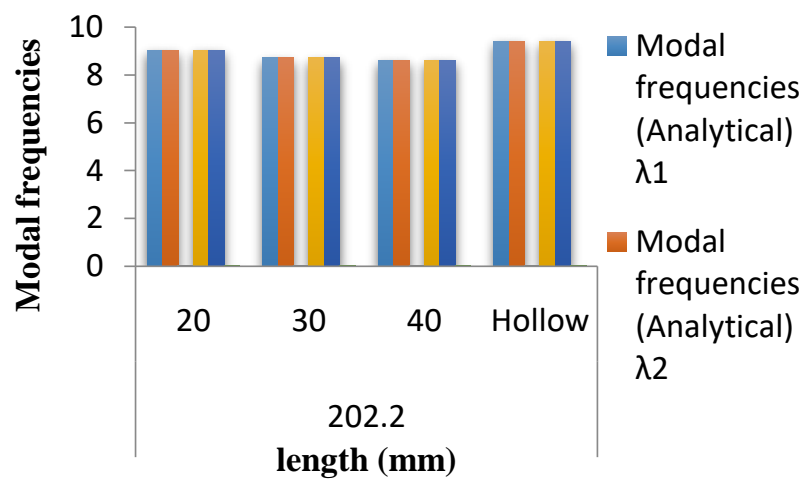

Chart 2: modal frequencies for a length of $202.2 \mathrm{~mm}$

Table 3: comparison of modal frequency for $254.2 \mathrm{~mm}$ length

\begin{tabular}{|c|c|c|c|c|c|c|c|}
\hline \multirow{3}{*}{$\mathrm{L}$} & \multirow{2}{*}{ Grades } & \multicolumn{3}{|c|}{$\begin{array}{c}\text { Modal } \\
\text { frequency(Analyt) }\end{array}$} & \multicolumn{3}{c|}{$\begin{array}{c}\text { Modal } \\
\text { frequency(MATLAB) }\end{array}$} \\
\cline { 2 - 8 } & $\mathrm{M}$ & $\lambda 1$ & $\lambda 2$ & $\lambda 3$ & $\lambda 1$ & $\lambda 2$ & $\lambda 3$ \\
\hline \multirow{4}{*}{254.2} & 20 & 7.15 & 7.15 & 0.01 & 7.15 & 7.15 & 0.01 \\
\cline { 2 - 8 } & 30 & 7.10 & 7.10 & 0.01 & 7.12 & 7.12 & 0.01 \\
\cline { 2 - 8 } & 40 & 7.06 & 7.06 & 0.01 & 7.06 & 7.06 & 0.01 \\
\cline { 2 - 8 } & Hollow & 8.22 & 8.22 & 0.01 & 8.22 & 8.22 & 0.01 \\
\hline
\end{tabular}

\section{Length v/s modal frequencies}

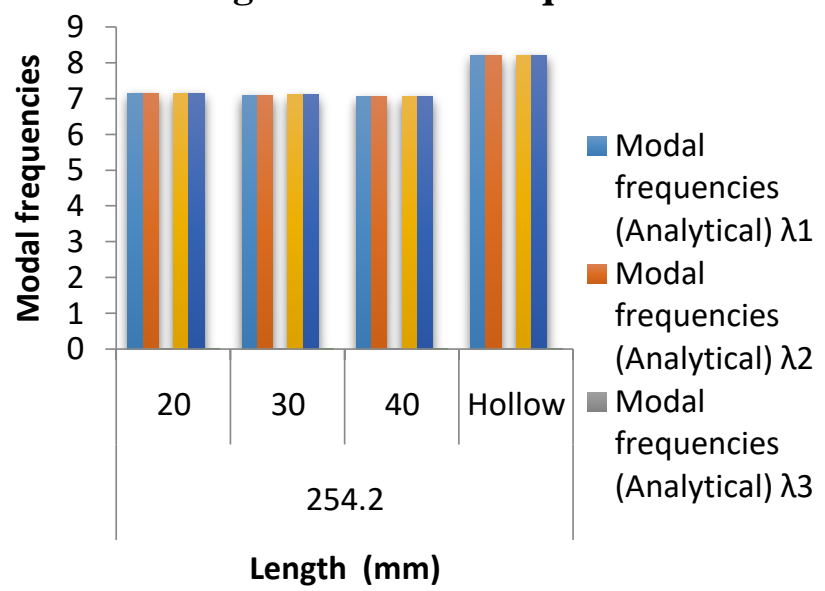

Chart 3: Modal frequency for $254.2 \mathrm{~mm}$ length

Table 4: Comparison of modal frequencies for $392.2 \mathrm{~mm}$ length

\begin{tabular}{|c|c|c|c|c|c|c|c|}
\hline \multirow{3}{*}{$\mathrm{L}$} & Grades & \multicolumn{3}{|c|}{$\begin{array}{c}\text { Modal frequency } \\
\text { (Analytical) }\end{array}$} & \multicolumn{3}{c|}{$\begin{array}{c}\text { Modal } \\
\text { frequency(MATLAB) }\end{array}$} \\
\cline { 2 - 8 } & $\mathrm{M}$ & $\lambda 1$ & $\lambda 2$ & $\lambda 3$ & $\lambda 1$ & $\lambda 2$ & $\lambda 3$ \\
\hline \multirow{4}{*}{392.2} & 20 & 5.80 & 5.80 & 0.01 & 5.80 & 5.80 & 0.01 \\
\cline { 2 - 8 } & 30 & 5.77 & 5.77 & 0.01 & 5.77 & 5.77 & 0.01 \\
\cline { 2 - 8 } & 40 & 5.61 & 5.61 & 0.01 & 5.61 & 5.62 & 0.01 \\
\cline { 2 - 8 } & Hollow & 6.41 & 6.41 & 0.01 & 6.41 & 6.41 & 0.01 \\
\hline
\end{tabular}




\section{Length v/s Modal frequencies}

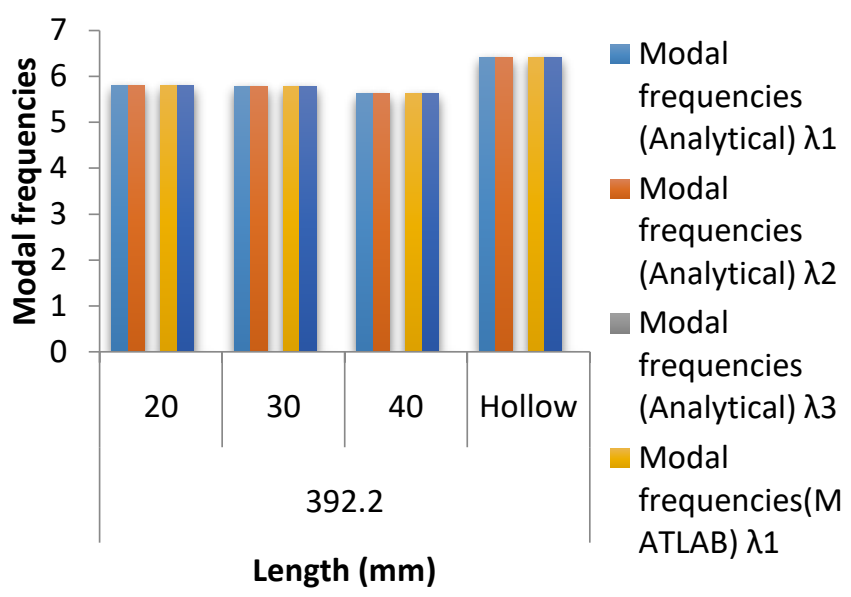

Chart 4: Modal frequencies for length of $392.2 \mathrm{~mm}$

Table 5: comparison of modal frequencies for $424 \mathrm{~mm}$

\begin{tabular}{|c|c|c|c|c|c|c|c|}
\hline \multicolumn{9}{|c|}{ length } \\
\hline \multirow{4}{*}{$\mathrm{L}$} & \multirow{3}{*}{ Grades } & \multicolumn{3}{|c|}{$\begin{array}{c}\text { Modal } \\
\text { frequency(Analytica } \\
\end{array}$} & & \multicolumn{3}{c|}{$\begin{array}{c}\text { Modal } \\
\text { frequency(MATLA } \\
\end{array}$} & $\mathrm{M}$ & $\lambda 1$ & $\lambda 2$ & $\lambda 3$ & $\lambda 1$ & $\lambda 2$ & $\lambda 3$ \\
\hline & 20 & 4.21 & 4.21 & 0.01 & 4.21 & 4.21 & 0.01 \\
\hline \multirow{4}{*}{42} & 30 & 4.08 & 4.08 & 0.01 & 4.08 & 4.08 & 0.01 \\
\cline { 2 - 8 } 4 & 40 & 4.05 & 4.05 & 0.01 & 4.05 & 4.05 & 0.01 \\
\cline { 2 - 8 } & Hollow & 4.74 & 4.74 & 0.01 & 4.74 & 4.74 & 0.01 \\
\hline
\end{tabular}

\section{Length v/s modal frequencies}

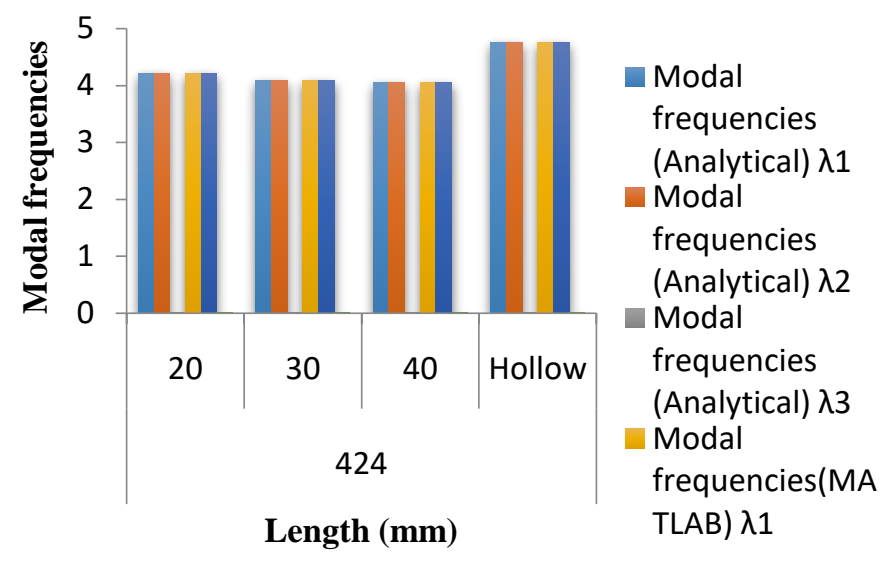

Chart 5: Modal frequency for $424 \mathrm{~mm}$ length
Load vs 202.2mm length of CFST

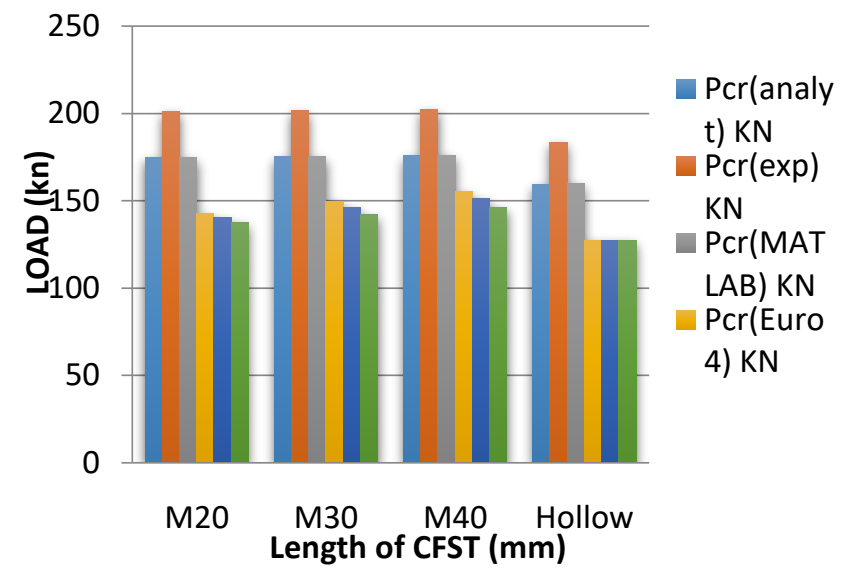

Chart 6: comparison of loads for $202.2 \mathrm{~mm}$ length

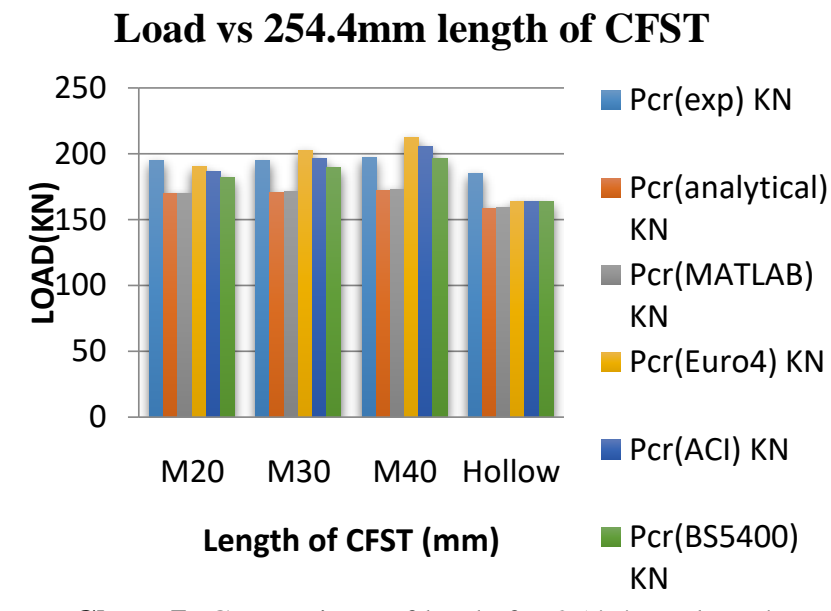

Chart 7: Comparison of loads for $254.4 \mathrm{~mm}$ length

\section{Load vs 339.2mm length of CFST}

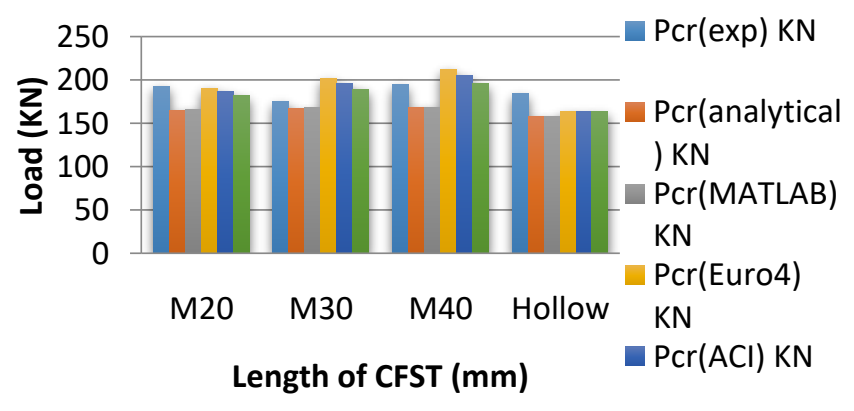

Chart 8: Comparison of loads for 339.2mm length 


\section{Load vs 424mm length of CFST}

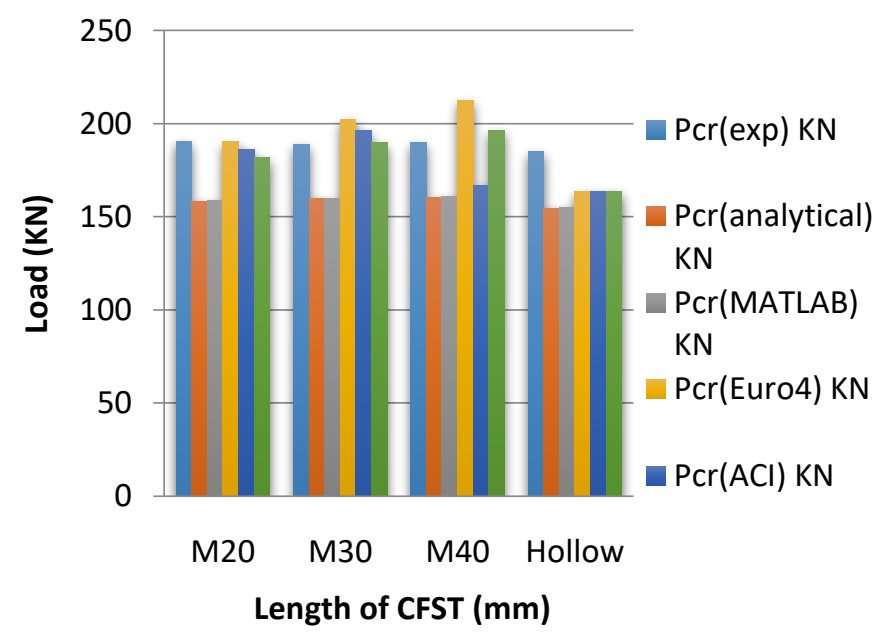

Chart 9: Comparison of loads for $424 \mathrm{~mm}$ length

\section{Load vs 508.8mm length of CFST}

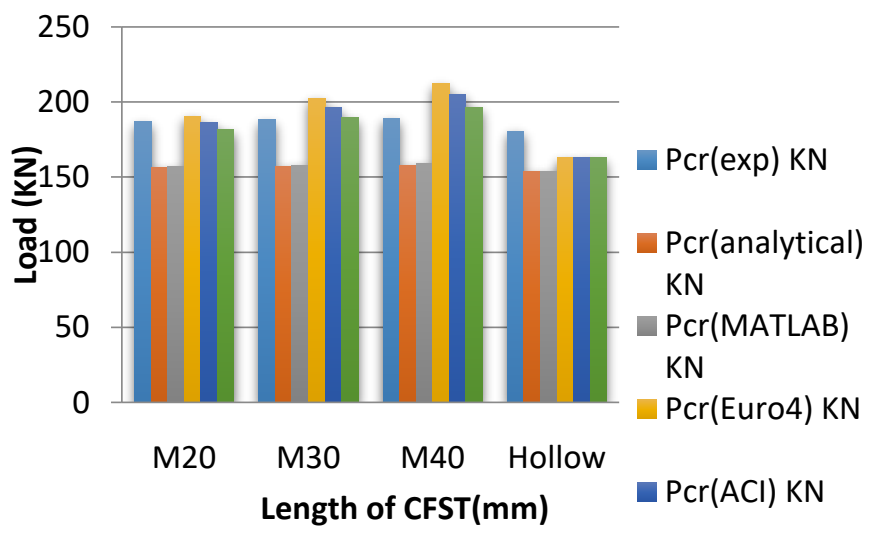

Chart 10: Comparison of loads for 508.8mm length

\section{Load vs 594.6mm length of CFST}

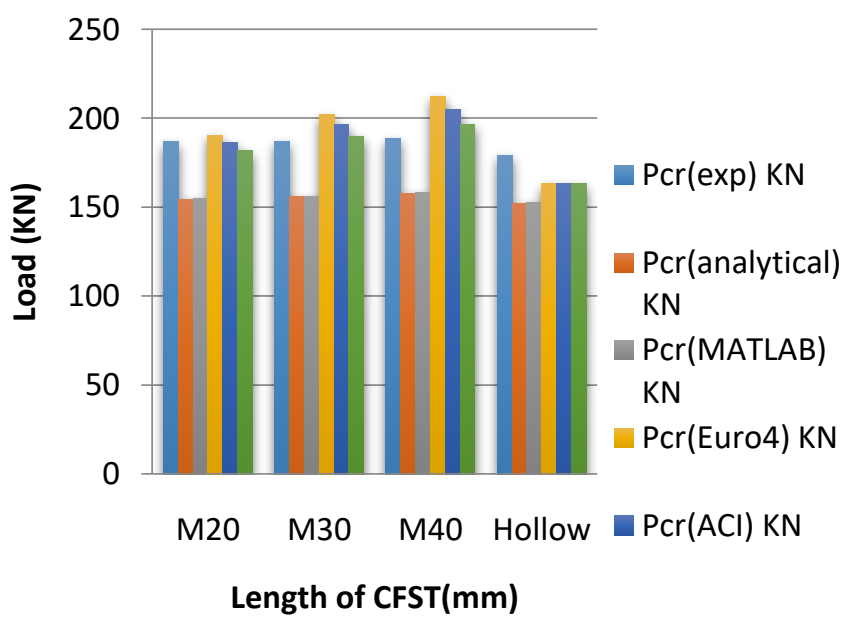

Chart 11: Comparison of loads for 594.6mm length

\section{Load vs 678.4mm length of CFST}

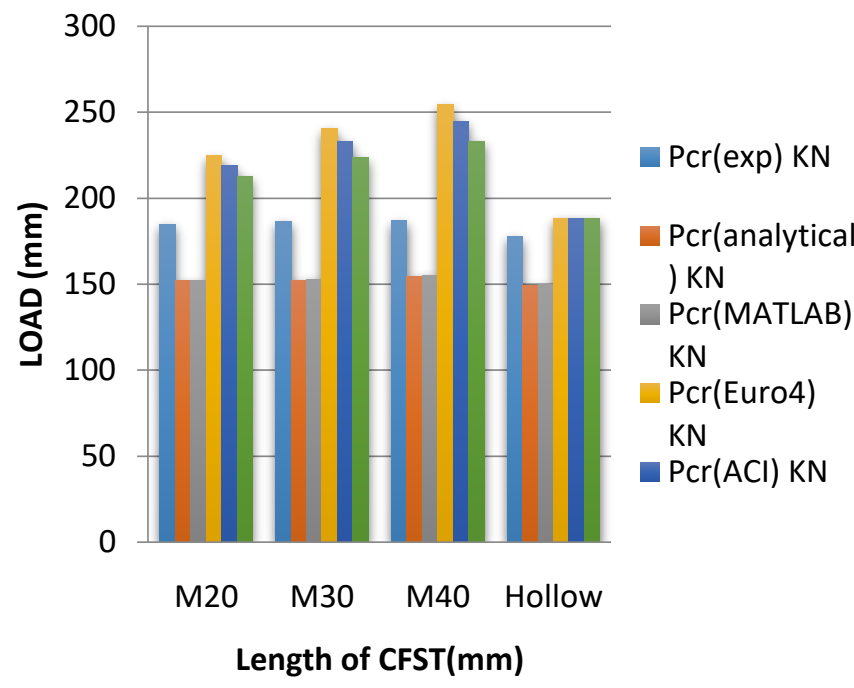

Chart 12: Comparison of loads for $678.4 \mathrm{~mm}$ length

\section{CONCLUSION}

In this study the following conclusions are drawn,

[1]. As the Column Length increases, the Load Carrying Capacity of CFST is decreased by $2.36 \%$.

[2]. As Slenderness Ratio (L/D) increases, Load Carrying Capacity of CFST is decreased by $2.36 \%$.

[3]. As Grades of Light Weight Concrete increases (i.e. M20, M30, and M40), Load Carrying Capacity of CFST column increased by $0.651 \%$ for a Column of Constant Length.

[4]. For Particular Grade of Concrete Load Carrying Capacity increased by 2 to $5 \%$ for 15 to $16 \%$ increased in Column Length.

[5]. For 15 to $16 \%$ increased in Column Length, Load Carrying Capacity is decreased by 1.5 to $5 \%$.

[6]. As Grades of Concrete increases and for 15 to $16 \%$ Column Length increases, then percentage increases in Load Carrying Capacity was found to be very nominal 0.5 to $1 \%$. [7]. For Short Columns $(\lambda<12)$, Ultimate Load obtained from developing MATLAB programming varying by $0.45 \%$ when compared with Analytical Results by referring the Journals of Load Bearing Capacity of Concrete Filled Steel Columns by the ARTIOMAS KURANOVAS' for M20 Grades of Concrete.

[8]. For Long Columns $(\lambda>12)$, Ultimate Load obtained from developing MATLAB programming varying by $0.419 \%$ when compared with Analytical Results by referring the Journals Of Load Bearing Capacity Of Concrete Filled Steel Columns by the ARTIOMAS KURANOVAS' for M20 Grades of Concrete.

[9]. For Short Columns $(\lambda<12)$, Ultimate Load obtained from developing MATLAB programming varying by $0.534 \%$ when compared with Analytical Results by referring the Journals Of Load Bearing Capacity Of Concrete Filled Steel Columns by the ARTIOMAS KURANOVAS' for M30 Grades Of Concrete. 
[10]. For Long Columns $(\lambda>12)$, Ultimate Load obtained from developing MATLAB programming varying by $0.39 \%$ when compared with Analytical Results by referring the Journals Of Load Bearing Capacity Of Concrete Filled Steel Columns by the ARTIOMAS KURANOVAS' for M30 Grades Of Concrete.

[11]. For Short Columns $(\lambda<12)$, Ultimate Load obtained from developing MATLAB programming varying by $0.618 \%$ when compared with Analytical Results by referring the Journals Of Load Bearing Capacity Of Concrete Filled Steel Columns by the ARTIOMAS KURANOVAS' for M40 grades of concrete.

[12]. For Long Columns $(\lambda>12)$, Ultimate Load obtained from developing MATLAB programming varying by $0.361 \%$ when compared with Analytical Results by referring the Journals Of Load Bearing Capacity Of Concrete Filled Steel Columns by the ARTIOMAS KURANOVAS' for M40 Grades Of Concrete.

[13]. For Short Columns $(\lambda<12)$, Ultimate Load obtained from developing MATLAB programming varying by $0.447 \%$ when compared with Analytical Results by referring the Journals Of Load Bearing Capacity Of Concrete Filled Steel Columns by the ARTIOMAS KURANOVAS' for Hollow CFST.

[14]. For Long Columns $(\lambda>12)$, Ultimate Load obtained from developing MATLAB programming varying by $0.433 \%$ when compared with Analytical Results by referring the Journals Of Load Bearing Capacity Of Concrete Filled Steel Columns by the ARTIOMAS KURANOVAS' for Hollow CFST.

[15]. Results obtained by developing MATLAB programming is compared with 3 different codes i.e. EUROCODE 4, ACI, BS5400, in which EUROCODE4 gives better results in comparison with Analytical, Experimental and MATLAB results.

[16]. As Length of Column increases, the Natural Frequency of column decreases by $20 \%$ to $25 \%$.

[17]. For Particular Grade of concrete, the Natural Frequency decreased by $20 \%$ to $25 \%$ (for $15 \%$ to $16 \%$ length increase)

[18]. As Grade of Concrete increases, the Natural Frequency found to decrease by $4 \%$ to $6 \%$. (Length being constant)

[19]. For Change in Length of Column, the Natural Frequency obtained from developing MATLAB programming varied between $2 \%$ to $2.5 \%$ when compared with Analytical results.

[20]. As Column Length increases, the Modal Frequencies were observed to decrease.

[21]. For Particular Grade of Concrete (for $12 \%$ to $16 \%$ of increased length), the Modal Frequencies decreased by $8 \%$ to $12 \%$.

[22]. For Constant Length and for increased grade of concrete, Modal Frequencies decreased by $3.5 \%$ to $5 \%$.

\section{REFERENCES}

[1] ACI (American Concrete Institute), Building code requirements for structural concrete and commentary, ACI318-95.
[2] Euro code 4 for design of composite steel structures, in part 1.1 general rules for buildings.

[3] Euro code 2 for properties of steel and concrete for design of composite steel structures.

[4] BS5400 for design of concrete filled steel columns, and for finding critical load of CFST columns.

[5] IJRET: International Journals of Research in Engineering and Technology dynamic behavior or composite filled circular steel tubes with light weight concrete as infilled.

[6] Zhijing Ou ${ }^{1}$; Baouchun Chen, P.E. ${ }^{2} ;$ Kai H. Hsieh ${ }^{3}$; experimental and analytical investigation of concrete filled steel tubular columns.

[7] Artiomas Kuranovas ${ }^{1}$, Douglas Goode $^{2}$,Audronis Kazimieras Kvedaras ${ }^{3}$,Shantong Zhong ${ }^{4}$ of "Load bearing capacity of concrete-filled steel columns".

[8] Structural Dynamics of Earthquake Engineering, theory and application uses of MATLAB by Rajashekaran.

[9] Concrete technology text book by the author of M S Shetty.

[10] www.google.com

\section{BIOGRAPHIES}

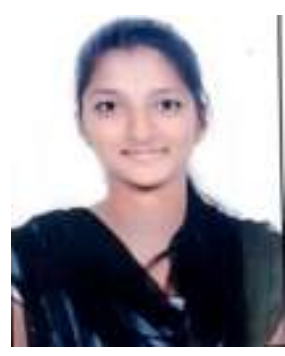

Graduated in the year 2016 from VTU, Belgaum. Presently perusing Master of Technology in Structural Engineering at Ghousia College of Engineering, Ramanagaram Also working on this topic for the dissertation under the guidance of Dr. N S Kumar.

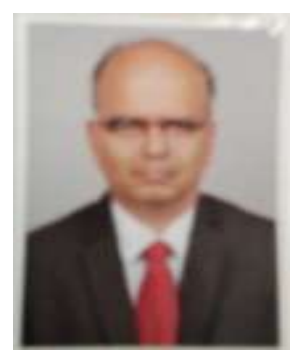

Involved in the Research field related to behavior of Composite Steel Column since a decade. Presently guiding 6 Ph.D Scholars (Research under VTU, Belgaum). Has more than 29 years of teaching experience \& 6 years of Research experience at Ghousia College of Engineering, Ramanagaram. 